Research article

Open Access

\title{
Tumor aromatase expression as a prognostic factor for local control in young breast cancer patients after breast-conserving treatment
}

\author{
Marc A Bollet ${ }^{1}$, Alexia Savignoni2 ${ }^{2}$, Leanne De Koning ${ }^{3}$, Carine Tran-Perennou 4 , \\ Catherine Barbaroux ${ }^{4}$, Armelle Degeorges ${ }^{4}$, Brigitte Sigal-Zafrani ${ }^{4}$, Geneviève Almouzni ${ }^{3}$, \\ Paul Cottu ${ }^{5}$, Rémy Salmon 6 , Nicolas Servant $7,8,9$, Alain Fourquet ${ }^{1}$ and Patricia de Cremoux ${ }^{4}$
}

\author{
1Department of Radiation Oncology, Institut Curie, 26 rue d'Ulm, 75248 Paris, France \\ 2Department of Biostatistics, Institut Curie, 26 rue d'Ulm, 75248 Paris, France \\ 3Laboratory of Nuclear Dynamics and Genome Plasticity (UMR 218), Institut Curie, 26 rue d'Ulm, 75248 Paris, France \\ ${ }^{4}$ Department of Tumour Biology, Institut Curie, 26 rue d'Ulm, 75248 Paris, France \\ 5Department of Medical Oncology, Institut Curie, 26 rue d'Ulm, 75248 Paris, France \\ ${ }^{6}$ Department of Surgery, Institut Curie, 26 rue d'Ulm, 75248 Paris, France \\ 7Department of Bio-informatics, Institut Curie, 26 rue d'Ulm, 75248 Paris, France \\ 8 INSERM, U900, 26 rue d'Ulm, 75248 Paris, France \\ ${ }^{9}$ Ecole des Mines de Paris, 35 rue Saint Honoré, 77300 , Fontainebleau, France
}

Corresponding author: Marc A Bollet, marc.bollet@curie.net

Received: 14 Mar 2009 Revisions requested: 27 Apr 2009 Revisions received: 18 Jun 2009 Accepted: 28 Jul 2009 Published: 28 Jul 2009

Breast Cancer Research 2009, 11:R54 (doi:10.1186/bcr2343)

This article is online at: http://breast-cancer-research.com/content/11/4/R54

(c) 2009 Bollet; licensee BioMed Central Ltd.

This is an open access article distributed under the terms of the Creative Commons Attribution License (http://creativecommons.org/licenses/by/2.0), which permits unrestricted use, distribution, and reproduction in any medium provided the original work is properly cited.

\begin{abstract}
Introduction We sought to determine whether the levels of expression of 17 candidate genes were associated with locoregional control after breast-conserving treatments of earlystage breast cancers in young, premenopausal women.

Methods Gene expression was measured by using RT-PCR in the breast tumors of a series of 53 young (younger than 40 years), premenopausal patients. All treatments consisted of primary breast-conserving surgery followed by whole-breast radiotherapy ( \pm regional lymph nodes) with or without systemic treatments (chemotherapy \pm hormone therapy). The median follow-up was 10 years.
\end{abstract}

Results The 10-year locoregional control rate was 70\% (95\% $\mathrm{Cl}, 57 \%$ to $87 \%$ ). In univariate analysis, no clinical/pathologic prognostic factors were found to be significantly associated with decreased locoregional control. Expression of three genes was found to be significantly associated with an increased locoregional recurrence rate: low estrogen-receptor $\beta$, low aromatase, and high GATA3. Two others were associated with only a trend $(P<0.10)$ : low $H E R 1$ and $S K P 2$. In multivariate analysis, only the absence of aromatase was significantly associated with an increased locoregional recurrence rate $(P=$ 0.003 ; relative risk $=0.49 ; 95 \% \mathrm{Cl} 0.29$ to 0.82 )

Conclusions Recent data give credit to the fact that breast cancer in young women is a distinct biologic entity driven by special oncogenic pathways. Our results highlight the role of estrogen-signaling pathways (mainly CYP19/aromatase, $G A T A 3$, and $E R-\beta)$ in the risk of locoregional recurrence of breast cancer in young women. Confirmation in larger prospective studies is needed.

\section{Introduction}

Breast-conserving therapy is the preferred treatment for patients with early-stage breast cancer [1]. It offers equal local control and overall survival [2], as well as superior psychosocial outcomes compared with modified radical mastectomy $[3,4]$. Locoregional recurrences can be traumatizing and even

CAF-1: chromatin assembly factor 1; CCNE1: cyclin E1; CCNE1: cyclin E2; Cl: confidence interval; CYP19: aromatase; EORTC: European Organisation for Research and Treatment of Cancer; ER: estrogen receptor; GATA3: GATA-binding protein 3; Gy: Gray; HER: human epidermal receptor; HR: hormone receptor; IGF1R: insulin-like growth factor 1-receptor; MKI67: antigen identified by monoclonal antibody ki-67; NCoA3/AIB1: nuclear receptor co-activator 3; NCoR: nuclear receptor co-repressor; PR: progesterone receptor; Pts: patients; RR: relative risk; RT-PCR: reverse transcriptase polymerase chain reaction; SKP2: S-phase kinase-associated protein 2; TBP: TATA box-binding protein. 
fatal, despite aggressive therapies [2]. Young age is generally considered to be the most important risk factor for locoregional recurrence after breast-conserving treatments [5-7]. This higher risk, which is not yet understood despite numerous studies, could find its explanation in tumor biology.

The hormonal environment, with menopause as its archetype epitome, is the major physiological difference between younger and older patients. Estrogens not only are the main regulators of growth and differentiation in the normal mammary gland, but also play a major role in the onset and progression of breast cancer [8,9] (reviewed by Yager [10]). Other signaling pathways, not directly related to estrogen receptors (ERs), also are involved in the growth of epithelial tissues.

In premenopausal breast cancer patients, little is known about the expression levels of genes that are directly or indirectly involved in hormone (especially ER) and growth factors signaling pathways. The aim of this study, conducted in a series of women diagnosed with invasive breast cancers before the age of 40 , was therefore to determine the relation between locoregional relapse, classic biopathologic factors, and the intratumoral levels of gene expression of 17 hormone receptors, growth-factor receptors, or proliferation genes: $E R \alpha, E R \beta$, progesterone receptor (PR), nuclear receptor co-repressor (NCoR), nuclear receptor coactivator 3 (NCoA3/AIB1), aromatase (CYP19), GATA-binding protein 3 (GATA3), human epidermal receptor (HER) 1 to 4, insulin-like growth factor 1 receptor (IGF1R), antigen identified by monoclonal antibody ki-67 (MKl67), cyclin E1 (CCNE1), cyclin E2 (CCNE1), Sphase kinase-associated protein 2 (SKP2), and the two subunits of chromatin assembly factor 1 (CAF-1 $p 150$ and CAF1 p60). Quantitative reverse-transcriptase polymerase chain reaction (RT-PCR) was chosen, as it is the most precise method to measure absolute levels of expression of selected target genes within a wide range, from very high to very low transcript levels $[11,12]$.

\section{Materials and methods}

\subsection{Patients and tissue specimens}

Between 1988 and 1999, 257 premenopausal women, younger than 40 years, with no previous history of cancer were treated at the Institut Curie for early unilateral breast cancers. The present retrospective study was based on 53 of these 257 patients for whom frozen tumor tissue was available. Median age at diagnosis was 37 years (range, 23 to 40 ) with $30 \%$ of patients (16 patients) no older than 36 years. Median follow-up was 10 years (range, 2 to 18 years).

Patient and tumor characteristics are reported in Table 1. Clinical stage [13] was either T1 or T2, N0 or N1. All specimens were reviewed by the same pathologist (BSZ). Histologic classification of the infiltrating carcinomas was reported according to the World Health Organization criteria, and histologic grade was reported according to Ellis and Elston [14]. The median number of mitoses, calculated per 10 high-power fields [15], was 13 (2 to 120). Hormone receptors (HRs) were positive when nuclear staining for either estradiol receptors (ERs) or progesterone receptors (PRs) was observed in at least 10\% of invasive cells with immunohistochemistry [16]. No pathologic axillary lymph node involvement was observed in 31 (58\%) patients.

This study was approved by the Institutional Review Board and Ethics committee. Patients were informed that their biologic samples could be used for research purposes and that they had the right to refuse if they so wished.

\subsection{Treatments}

Surgery consisted of breast-conserving procedures as firstline treatment in all cases. The quality of the surgical margins was classified as wide (more than $3 \mathrm{~mm}$ ) in $32(65 \%)$ patients, close ( $3 \mathrm{~mm}$ or less) in $11(22 \%)$ patients, involved with ductal carcinoma in situ in $2(4 \%)$ patients, involved with invasive carcinoma in $4(8 \%)$ patients, and unknown in 4 patients. Axillary lymph node dissection was performed in all patients.

Patients received posttumorectomy radiotherapy with a median dose of 51 Gy (range, 45 to 54 Gy) to the breast. A boost to the tumor bed was performed for $40(75 \%)$ of patients with a median dose of 16 Gy (range, 7 to 25 Gy). The median total dose to the tumor bed was 66 Gy (range, 50 to 75 Gy). Supraclavicular irradiation was performed in 27 (51\%) of patients. Internal mammary irradiation was performed in 38 $(72 \%)$ of patients. In the case of lymph node involvement, the internal mammary chain and the supraclavicular area were both irradiated. In the absence of lymph node involvement, irradiation of the internal mammary chain, with or without the supraclavicular area, was indicated for centrally located tumors with histopathologic features of aggressiveness. Axillary irradiation was added in the presence of extensive axillary involvement or in the absence of axillary lymph node dissection.

No protocol to boost all young patients with negative surgical margins was available at that time, and some patients reported in this series were accrued in the EORTC boost trial that randomized between boost and no boost from 1989 to 1996 $[5,17,18]$. In the case of positive surgical margins, a radiotherapy boost of generally 20 to 28 Gy was added to the wholebreast irradiation. For patients not participating in the EORTC randomized trial, a boost of 10 to 16 Gy was added in the case of aggressive histopathologic features (unsatisfactory margins, high histopathologic grade, high proliferation index, absence of hormone receptors).

The reasons for absence of repeated excision were not always specified, but when they were specified, the reasons were the patient's choice not to undergo a new surgical procedure that could have been mastectomy. 
Table 1

\begin{tabular}{|c|c|c|c|c|c|}
\hline \multirow[b]{2}{*}{ Total } & \multicolumn{2}{|c|}{ RT-PCR series } & \multicolumn{2}{|c|}{ Whole series } & \multirow[b]{2}{*}{$P$} \\
\hline & $n$ & $\%$ & $n$ & $\%$ & \\
\hline Family history of breast cancer (MD $=0$ and 1$)^{a}$ & & & & & 0.77 \\
\hline Without & 42 & 79 & 198 & 77 & \\
\hline With & 11 & 21 & 58 & 23 & \\
\hline \multicolumn{6}{|l|}{ Age $(M D=0 \text { and } 0)^{a}$} \\
\hline Median (min-max) in years & $37(23-40)$ & & $37(23-40)$ & & 0.71 \\
\hline$\leq 35$ years old & 37 & 70 & 176 & 68 & 0.85 \\
\hline$>35$ years old & 16 & 30 & 81 & 32 & \\
\hline Clinical $\mathrm{T}$ stage $(\mathrm{MD}=0 \text { and } 0)^{\mathrm{a}}$ & & & & & 0.0496 \\
\hline cT0-1 & 31 & 58 & 186 & 72 & \\
\hline cT2 & 22 & 42 & 71 & 28 & \\
\hline Clinical $\mathrm{N}$ stage $(\mathrm{MD}=0 \text { and } 0)^{\mathrm{a}}$ & & & & & 0.70 \\
\hline No & 52 & 98 & 246 & 96 & \\
\hline $\mathrm{N} 1$ & 1 & 2 & 11 & 4 & \\
\hline Type of invasive carcinoma (MD $=0$ and 0$)^{a}$ & & & & & $0.18^{b}$ \\
\hline Ductal & 46 & 87 & 223 & 87 & \\
\hline Lobular & 6 & 11 & 16 & 6 & \\
\hline Other & 1 & 2 & 18 & 7 & \\
\hline Histologic grade (MD = 0 and 1$)^{a}$ & & & & & $0.03^{b}$ \\
\hline $1-2$ & 14 & 26 & 110 & 43 & \\
\hline 3 & 36 & 68 & 120 & 47 & \\
\hline Unclassifiable & 3 & 6 & 26 & 10 & \\
\hline Estrogen receptor (ER) (MD $=6$ and 37$)^{\mathrm{a}}$ & & & & & 0.59 \\
\hline ER- & 10 & 21 & 55 & 25 & \\
\hline $\mathrm{ER}^{+}$ & 37 & 79 & 165 & 75 & \\
\hline Progesterone receptor $(\mathrm{PR})(\mathrm{MD}=6 \text { and } 39)^{\mathrm{a}}$ & & & & & 0.84 \\
\hline PR- & 9 & 19 & 39 & 18 & \\
\hline $\mathrm{PR}^{+}$ & 38 & 81 & 179 & 82 & \\
\hline Hormone receptors (HRs) $(\mathrm{MD}=6 \text { and } 37)^{\mathrm{a}}$ & & & & & 0.87 \\
\hline $\mathrm{HR}^{-}$ & 7 & 15 & 35 & 16 & \\
\hline $\mathrm{HR}^{+}$ & 40 & 85 & 185 & 84 & \\
\hline Lymphovascular involvement (MD $=3$ and 43$)^{a}$ & & & & & 0.0004 \\
\hline Absent & 33 & 66 & 188 & 88 & \\
\hline Present & 17 & 34 & 26 & 12 & \\
\hline Histologic $\mathrm{T}$ stage $(\mathrm{MD}=5 \text { and } 12)^{\mathrm{a}}$ & & & & & 0.89 \\
\hline pT1 & 34 & 71 & 176 & 72 & \\
\hline pT2 & 14 & 29 & 69 & 28 & \\
\hline
\end{tabular}




\begin{tabular}{|c|c|c|c|c|c|}
\hline Histologic $N$ stage $(M D=0 \text { and } 34)^{a}$ & & & & & 0.06 \\
\hline pNO & 31 & 58 & 182 & 73 & \\
\hline $\mathrm{pN} 1-3$ & 22 & 42 & 41 & 27 & \\
\hline Surgical margins ( $M D=4$ and 10$)^{a}$ & & & & & 0.10 \\
\hline Satisfactory ( $\geq 3 \mathrm{~mm})$ & 32 & 65 & 129 & 52 & \\
\hline Unsatisfactory & 17 & 35 & 118 & 48 & \\
\hline Systemic therapy $(\mathrm{MD}=0 \text { and } 0)^{\mathrm{a}}$ & & & & & 0.0001 \\
\hline None & 16 & 30 & 151 & 59 & \\
\hline Hormone therapy $(\mathrm{HT})$ only & 0 & 0 & 101 & 39 & \\
\hline Chemotherapy $\pm \mathrm{HT}$ & 37 & 70 & 5 & 2 & \\
\hline \multicolumn{6}{|l|}{ Total RT dose $(\mathrm{MD}=0)^{\mathrm{a}}$} \\
\hline Median (min-max) in Gy & $66(50-75)$ & & $64(0-80)$ & & 0.14 \\
\hline$<60 \mathrm{~Gy}$ & 13 & 25 & 101 & 39 & 0.043 \\
\hline$\geq 60 \mathrm{~Gy}$ & 40 & 75 & 156 & 61 & \\
\hline
\end{tabular}

Characteristics of the rt-PCR series (53 patients) in comparison to the whole population of consecutive patients with the same selection criteria treated over the same period (1988-1999) at the Institut Curie (257 patients). MD = missing data (both in the rt-PCR and in the whole series); total RT dose = total radiotherapy dose to the tumor bed (whole-breast radiotherapy dose + boost dose). a0.37 when the comparison excluded

histologic types other than ductal or lobular. ${ }^{b} 0.05$ when the comparison included all histologic grades.

No systemic therapy was administered in 16 (30\%) patients. Chemotherapy only was given to 23 (43\%) patients, consisting of anthracycline-based combination chemotherapy in most cases (usually six cycles of 5-fluorouracil, doxorubicin, and cyclophosphamide). A combination of chemotherapy and hormone therapy (tamoxifen for 5 years) was administered to 14 (26\%) patients.

\subsection{RNA isolation, RT-PCR}

Total RNA was extracted from frozen tumor samples and firststrand cDNA synthesis was performed, as previously described from $1 \mu \mathrm{g}$ of total RNA by using Superscript II RT (Invitrogen, Carlsbad, CA, USA) [19]. ER $\alpha, E R \beta, P R, H E R 1$ to HER4, MKi67, Cyclin E1 and E2, GATA3, IGF1-R, NCor, NCoA3, CYP19 (aromatase gene), SKP2 and CAF-1 p150, and $C A F-1 p 60$ transcripts were quantified by using real-time quantitative reverse transcription-PCR assays. The nucleotide and probe sequences and the conditions of PCR were described previously for $E R \alpha, E R \beta, P R$, HER1 to HER4, MKi67, cyclin E1 and E2, NCor, NCoA3, CYP19 [see Additional data file 1] $[19,20]$. GATA3, IGF1R were quantified by Assays-on-Demand from Applied Biosystems (Applied Biosystems, Inc., Foster City, CA). The nucleotide and probe sequences SKP2 and CAF-1 were chosen with the help of Primer express software (Applied Biosystems). TBP (TATA box binding protein) was used as the endogenous reference gene for immediate quantification of transcripts. Searches were conducted in dbEST, htgs, and $\mathrm{nr}$ data bases [21] to confirm the total gene specificity of nucleotide sequences.
Primers were placed at the junction between two exons. All PCRs were performed in duplicate by using ABI Prism 7700 Sequence Detection System (Perkin Elmer Applied Biosystems) and the Core reagent kit (Eurogentec). A 5- $\mu$ l diluted sample of cDNA (12.5 ng) was added to $20 \mu \mathrm{l}$ of the PCR mix. The thermal-cycling conditions comprised an initial denaturation step at $95^{\circ} \mathrm{C}$ for $10 \mathrm{~min}$, and 45 cycles at $95^{\circ} \mathrm{C}$ for $15 \mathrm{~s}$ and either $60^{\circ} \mathrm{C}$ or $65^{\circ} \mathrm{C}$, depending on the target, for $1 \mathrm{~min}$.

Results were expressed as $\mathrm{N}$-fold differences in target gene expression relative to a reference gene defined as " $\mathrm{N}$ target" (arbitrary units) and was determined as follows:

$$
\mathrm{N} \text { target }=\mathrm{E}_{\text {target }}^{(\text {C tcalbrator-C tsampl })} / \mathrm{E}_{\text {reference gene }}^{(\text {C tcalibator-C tsample })}
$$

where $E$ is the efficiency of PCR measured by using the slope of the calibration curve, and $\mathrm{Ct}$ is the cycle threshold.

\subsection{Statistical analysis}

Survival rates, defined from the date of surgery to the occurrence of the event, were estimated by using the Kaplan-Meier estimate; groups were compared by using the log-rank test. Event-free patients were censored at the date of their last known contact or death. Local relapses were defined as the occurrence of breast carcinoma (either invasive or ductal carcinoma in situ) in the treated breast. Locoregional relapses were our primary end point and were defined as either a local relapse or a recurrence in the ipsilateral lymph node areas (axillary, internal mammary, supraclavicular). Contralateral 
breast cancers could be either ductal in situ or infiltrating carcinoma. Distant disease was defined as disease occurring elsewhere than in the contralateral breast or locoregional site. Disease-free was defined as the absence of locoregional or distant relapses or both. Survival rates and relative risks (RRs) are presented with their 95\% confidence intervals (Cls). Annual risks were calculated and plotted. The RT-PCR series of 53 patients was compared with the whole series of all consecutive patients treated over the same period (1988 through 1999 ) at the Institut Curie (257 patients) after exclusion of the RT-PCR patients. All gene expressions were analyzed as continuous variables to avoid having to search for cut-off values. Fisher's Exact or $\chi^{2}$ tests were used to compare percentages, as appropriate. Univariate analyses were performed to identify prognostic factors of outcome and to estimate crude relative risks (RRs). The influence of each factor, adjusted to the others, was assessed in a multivariate analysis by the Cox proportional hazards model [22]. A stepwise modeling algorithm was used, with a limit of significance of 0.10 for entering and 0.05 for removing risk factors. The limit of significance was 0.05 . Analyses were performed by using $\mathrm{R}$ software, 2.5.0.

\section{Results}

The comparison of our series of patients with unselected, consecutive patients is summarized in Table 1. The patients analyzed with RT-PCR had tumors of higher clinical stage, higher histologic grade, and more lymphovascular invasion, and more often received chemotherapy and a total dose to the tumor bed higher than 60 Gy. All other patient, tumor, and treatment characteristics were similar.

Fifteen locoregional recurrences occurred (13 only local, 2 local and regional). Five-year and 10-year locoregional control rates were $82 \%(95 \% \mathrm{Cl}, 72 \%$ to $93 \%)$ and $70 \%(95 \% \mathrm{Cl}$, $57 \%$ to $87 \%$ ), respectively. All local recurrences occurred in the same quadrant as the primary tumor. Treatment of the local recurrence included salvage mastectomy with or without systemic therapy in 11 (73\%) patients. In three (6\%) patients, contralateral breast cancer developed. In 15 patients, distant metastases developed. Five-year and 10-year distant diseasefree survival rates were $82 \%(95 \% \mathrm{Cl}, 72 \%$ to $93 \%)$ and $69 \%$ (95\% Cl, 56\% to $85 \%)$, respectively. Five-year and 10-year overall survival rates were $85 \%(95 \% \mathrm{Cl}, 76 \%$ to $95 \%)$ and $78 \%$ (95\% Cl, $65 \%$ to $92 \%$ ), respectively. In no patient did a second non-breast cancer develop.

Because regional recurrence was always accompanied by local recurrence, risk factors for local and locoregional recurrence were the same (data not shown). In univariate analysis, no clinicopathologic prognostic factor was found to be significantly associated with decreased locoregional control (Table 2). In univariate analysis, three gene-expression levels were found to be significantly associated with an increased locoregional recurrence rate: low $E R \beta$, low aromatase, high GATA3 (Table 3 ). Two other factors were associated only with a trend
$(P<0.10)$ : low $H E R 1$ and SKP2. Multivariate analysis was performed, taking the factors associated $(P<0.10)$ with locoregional recurrence into account in a Cox model (that is, 5 RTPCR features (ER $\beta, H E R 1, G A T A 3$, SKP2 and aromatase). Only low tumor expression of aromatase was significantly associated with an increased locoregional recurrence rate ( $P$ $=0.003$; relative risk $=0.49 ; 95 \% \mathrm{Cl}, 0.29$ to 0.82 ). Locoregional-free recurrence interval according to the level of intratumoral expression of aromatase with a cut-off at 5 is displayed in Figure 1. GATA-3 was associated with a trend toward an increased locoregional recurrence rate $(P=0.06$; relative risk $=1.49 ; 95 \% \mathrm{Cl}, 0.02$ to 2.39 ).

Associations between gene expressions and locoregional recurrences were looked for in two publicly available microarray studies by Kreike and colleagues [23] and Nuyten and associates [24] that gave information regarding the age of the young women (48 and 35 patients with 18 and 7 local recurrences, respectively) treated with breast-conserving treatments with whole-breast radiotherapy. They both failed to show an association between the gene expression of either aromatase or gata3 and local recurrences [see Additional data file 2].

\section{Discussion}

This study was based on a series of 53 premenopausal women younger than 40 years with a long (10 years) follow-up treated at the Institut Curie for invasive breast cancer with primary breast-conserving surgery. Given the specificity of the hormonal environment in young patients, genes directly or indirectly involved in hormone and growth-factor signaling pathways were analyzed. In addition to the usual clinical and histopathologic features, the levels of expression of 17 candidate genes for an association with locoregional control also were examined.

\section{Figure 1}

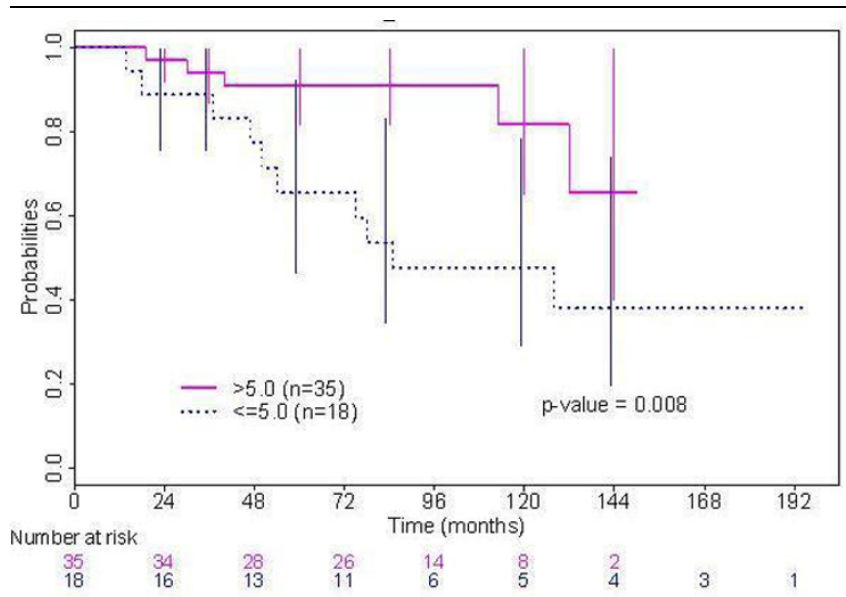

Locoregional-free recurrence interval according to the level of intratumoral expression of aromatase. 
Table 2

Univariate analysis of clinical and histopathologic prognostic factors for locoregional control

\begin{tabular}{|c|c|c|c|c|}
\hline & \multicolumn{4}{|c|}{ rt-PCR series } \\
\hline & $n$ & $\begin{array}{l}\text { 10-year LRC (\%) } \\
{[95 \% \mathrm{Cl}]}\end{array}$ & $P a$ & $\mathrm{RR}[95 \% \mathrm{Cl}]$ \\
\hline Family history of breast cancer & & & 1.0 & \\
\hline No & 42 & $70[56-87]$ & & 1 \\
\hline Yes & 11 & NA & & $1[0.22-4.59]$ \\
\hline Age (continuous variable) & & & 0.38 & $0.94[0.83-1.07]$ \\
\hline Age (years; dummy variable) & & & 0.57 & \\
\hline$>35$ & 16 & 73 [59-90] & & 1 \\
\hline$\leq 35$ & 37 & $60[32-100]$ & & $1.37[0.47-4.0]$ \\
\hline Clinical tumor stage & & & 0.71 & \\
\hline $\mathrm{cT} 1$ & 31 & $70[53-91]$ & & 1 \\
\hline cT2 & 22 & $74[56-96]$ & & $0.81[0.28-2.39]$ \\
\hline Histologic T stage & & & 0.55 & \\
\hline pT1 & 34 & 70 [54-91] & & 1 \\
\hline pT2 & 14 & $70[49-100]$ & & $0.71[0.24-2.13]$ \\
\hline Surgical margin & & & 0.70 & \\
\hline$\geq 3 \mathrm{~mm}$ & 32 & $61[43-86]$ & & 1 \\
\hline$<3 \mathrm{~mm}$ & 17 & $81[64-100]$ & & $0.81[0.27-2.37]$ \\
\hline Lymphovascular invasion & & & 0.78 & \\
\hline Absent & 33 & $71[56-91]$ & & 1 \\
\hline Present & 17 & $71[50-100]$ & & $1.18[0.36-3.87]$ \\
\hline Histologic $\mathrm{N}$ stage & & & 0.54 & \\
\hline $\mathrm{pNO}$ & 31 & $63[47-84]$ & & 1 \\
\hline $\mathrm{pN} 1$ & 16 & $78[53-100]$ & & $0.49[0.13-1.77]$ \\
\hline $\mathrm{pN} 2$ & 6 & $80[52-100]$ & & $0.77[0.17-3.52]$ \\
\hline Histologic type & & & 0.14 & \\
\hline Ductal & 46 & 75 [63-90] & & 1 \\
\hline Lobular & 6 & $33[7-100]$ & & $2.61[0.72-9.53]$ \\
\hline Estrogen receptors (ERs) & & & 0.14 & \\
\hline ER- & 10 & $90[73-100]$ & & 1 \\
\hline $\mathrm{ER}^{+}$ & 37 & $63[47-85]$ & & $4.28[0.55-33.27]$ \\
\hline Progesterone receptors (PR) & & & 0.84 & \\
\hline PR- & 9 & $71[43-100]$ & & 1 \\
\hline $\mathrm{PR}^{+}$ & 38 & 69 [53-88] & & $1.18[0.26-5.27]$ \\
\hline Hormone receptors (HRs) & & & 0.48 & \\
\hline ER- and PR- & 7 & $86[63-100]$ & & 1 \\
\hline $\mathrm{ER}^{+}$or $\mathrm{PR}^{+}$ & 40 & $67[52-86]$ & & $2.1[0.06-3.72]$ \\
\hline Histopathologic index & & & 0.59 & \\
\hline Grade 1-2 & 14 & $64[35-100]$ & & 1 \\
\hline Grade 3 & 36 & 73 [59-91] & & $0.70[0.39-5.19]$ \\
\hline Systemic therapy & & & 0.35 & \\
\hline None & 16 & 54 [33-86] & & 1 \\
\hline ChT & 23 & 85 [70-100] & & $0.47[0.15-1.49]$ \\
\hline $\mathrm{ChT}+\mathrm{HT}$ & 14 & $43[11-100]$ & & $0.48[0.12-1.90]$ \\
\hline Total RT doseb & & & 0.27 & \\
\hline$\geq 60 \mathrm{~Gy}$ & 43 & 76 [59-97] & & 1 \\
\hline$<60$ Gy & 13 & $50[28-88]$ & & $1.8[0.63-5.15]$ \\
\hline
\end{tabular}

$\mathrm{NA}=$ not applicable; $\mathrm{Cl}=$ confidence interval; $\mathrm{RR}=$ relative risk for locoregional recurrence. ${ }^{a} P$ values pertain to the relative risks. ${ }^{b} T o t a l$ dose of radiotherapy to the tumor bed (whole breast dose + boost dose). 
Table 3

\begin{tabular}{|c|c|c|c|c|}
\hline \multirow[t]{2}{*}{ Gene expression by quantitative rt-PCR (continuous variables) } & \multicolumn{2}{|c|}{ Univariate analysis } & \multicolumn{2}{|c|}{ Multivariate analysis } \\
\hline & $\begin{array}{l}\text { HR (RR) } \\
{[95 \% \mathrm{Cl}]}\end{array}$ & $P$ & $\begin{array}{l}\mathrm{HR}(\mathrm{RR}) \\
{[95 \% \mathrm{Cl}]}\end{array}$ & $P$ \\
\hline Estrogen receptor- $\alpha$ & $1.22[0.90-1.66]$ & 0.15 & & \\
\hline Estrogen receptor- $\beta$ & $0.61[0.39-0.95]$ & 0.04 & & 0.54 \\
\hline Progesterone receptor & $1.13[0.88-1.45]$ & 0.32 & & \\
\hline HER1 & $0.65[0.37-1.13]$ & 0.10 & & 0.72 \\
\hline HER2 & $0.89[0.64-1.25]$ & 0.49 & & \\
\hline HER3 & $1.06[0.55-2.02]$ & 0.87 & & \\
\hline HER4 & $1.22[0.91-1.63]$ & 0.14 & & \\
\hline MKI 67 & $0.89[0.61-1.30]$ & 0.56 & & \\
\hline Cyclin E1 & $0.81[0.48-1.36]$ & 0.43 & & \\
\hline Cyclin E2 & $0.75[0.49-1.14]$ & 0.18 & & \\
\hline GATA 3 & $1.61[0.95-2.73]$ & 0.04 & 1.49 [0.92-2.39] & 0.06 \\
\hline IGF1R & $1.41[0.93-2.14]$ & 0.13 & & \\
\hline NCoR & $0.90[0.38-2.15]$ & 0.82 & & \\
\hline NCoA3/AIB1 & $0.51[0.21-1.22]$ & 0.14 & & \\
\hline CYP19 (aromatase) & $0.48[0.28-0.80]$ & 0.003 & $0.49[0.29-0.82]$ & 0.003 \\
\hline Skp2 & $0.52[0.23-1.17]$ & 0.10 & & 0.18 \\
\hline CAF-1 p150 & $1.00[0.48-2.12]$ & 1.00 & & \\
\hline CAF-1 p60 & $1.00[0.97-1.03]$ & 0.94 & & \\
\hline
\end{tabular}

$\mathrm{RR}=$ relative risk for locoregional recurrence calculated with the nonparametric Cox model; $\mathrm{Cl}=$ confidence interval; $\mathrm{HER}=$ human epidermal receptor. Because of lack of prognostic values of the clinical variables in univariate analysis, none was entered in the multivariate analysis.

To verify that these findings could be extrapolated, we compared the characteristics of patients and tumors of the 53 patients included in this study with the 257 other patients treated over the same period (1988 through 1999) at the Institut Curie who met the same inclusion criteria (age, medical history, therapeutic sequence) (Table 1). This comparison showed that this RT-PCR series consisted of patients with tumors with a more advanced clinical stage, higher histologic grade, and more lymphovascular invasion and who therefore more frequently received chemotherapy and a total dose to the tumor bed higher than 60 Gy. All other patient, tumor, and treatment characteristics were comparable. It could be hypothesized that these differences were due, at the time of this study (1988 to 1999), to technical parameters: tissue samples for frozen storage would be easier to obtain from larger tumors.

In this series of 53 patients, neither clinical nor pathologic features were associated with increased locoregional recurrence rates. Very young age, in particular, was not significantly associated with increased locoregional recurrences, in contrast with a previous study of unselected young patients from the Institut Curie [6].

RNA expressions of 17 target genes were studied here with RT-PCR for their association with locoregional control. They are involved in hormone signaling, either directly $(E R \alpha, E R \beta$, PR, NCoA3/AIB1, NCoR, GATA3, CYP19/aromatase, $S K P 2)$ or indirectly (HER family, IGF1-R) or in proliferation (MKi67, cyclins E, and CAF-1). Classic hormone receptors $(E R \alpha, P R)$ have been extensively explored in breast cancers [10]. In contrast with previously published studies [25], a high frequency of young women in this series had positive hormone receptors ( $E R \alpha$ and $P R$ in $79 \%$ and $81 \%$ of cases with immunohistochemistry, and in $75 \%$ and $82 \%$ of cases with RTPCR).

Among the genes activated in response to ER activation (NCoA3/AIB1, NCoR, SKP2, GATA3, CYP19/aromatase), only the absence of CYP19/aromatase was significantly associated with an increased locoregional recurrence rate $(P=$ 0.003 ; relative risk $=0.49 ; 95 \% \mathrm{Cl}, 0.29$ to 0.82$)$. Given the 
small size of this series, it also is noteworthy that the level of GATA-3 was associated with a trend toward an increased locoregional recurrence rate $(P=0.06$; relative risk $=1.49$; $95 \% \mathrm{Cl}, 0.02$ to 2.39). CYP19/aromatase plays a critical role in breast cancer development by converting androgen into estrogens. CYP19/aromatase mRNA and protein have previously been detected in both tumor stroma and parenchymal cells in breast cancer tissue [26]. Previous data demonstrated that CYP19/aromatase mRNA is correlated with CYP19/aromatase enzymatic activity in cultured breast tumor fibroblasts [27]. The importance of in situ estrogen production has been demonstrated in breast carcinoma [28], where it is higher than that in normal breast tissue $[29,30]$. Inhibition of the aromatase pathway is considered to be clinically useful to reduce progression of breast tumors in postmenopausal women [31]. An apparently paradoxic finding was that a low level of CYP19/ aromatase transcripts in this population of young, premenopausal patients was significantly associated with an increased locoregional recurrence rate. However, preclinical studies demonstrated that estrogens or estrogenic compounds repress the transcriptional control of CYP19/aromatase $[32,33]$. It can be hypothesized that, in premenopausal women, who already have high plasma estradiol levels, the level of aromatase transcripts may be inversely correlated with the plasma estradiol level [34]. Low tumor expression of CYP19/aromatase would reflect a high level of circulating estrogen and would therefore be associated with poor outcome. This finding is supported by a study by Zhang and colleagues [35] in a series of 162 invasive ductal breast carcinomas that showed that aromatase mRNA levels were lower in patients younger than 50 years, with tumors larger than $2 \mathrm{~cm}$ and with axillary lymph node involvement [35].

However, the association between tumor aromatase expression and outcome remains controversial; no consistent correlation between aromatase immunoreactivity, activity, or mRNA level and known clinicopathologic factors or outcome has been conclusively reported [35-40]. Some authors have even reported, in univariate analysis, a correlation between high tumor aromatase activity and poor outcome $[37,40]$.

The association between tumor aromatase activity or expression and estrogen receptors is also very controversial, as some authors have reported a positive correlation $[35,36,40]$, whereas others have reported no correlation [37], or even an inverse correlation [39]. In the present series, no correlation was observed between aromatase expression and either age, hormone receptors, or histologic grade (data not shown).

GATA3 is a transcription factor involved in human growth and differentiation. Gene-expression profiling has shown that GATA3 is highly expressed in luminal $\mathrm{A}$ and $\mathrm{B}$ subtypes of cancer and closely related to $E R \alpha$ [41-43]. This study, the first to our knowledge to use quantitative RT-PCR in a population of young patients, showed a trend toward an association between a high level of GATA3 expression and higher locoregional recurrence rates. The favorable outcome in very young patients with ER-positive breast cancers is a controversial issue. Aebi and associates [44] reported a series of 3,500 premenopausal women treated in four randomized trials from the International Breast Cancer Study Group (IBCSG). They found that younger patients with ER-positive tumors had a significantly poorer disease-free survival than did younger patients with ER-negative tumors.

In addition, conflicting data have been published regarding the independent prognostic value of GATA3 in unselected breast cancer. Some studies found GATA3 to be associated with good prognosis $[45,46]$. The study by Voduc and colleagues [47] found no independent prognostic value of GATA3 in 3,119 breast cancer patients with immunohistochemistry on tissue microarrays.

$E R \beta$ expression in breast (normal and tumor) and the relation between ER $\beta$ and other clinicopathologic features and its role in hormone therapy have been extensively investigated (recently reviewed by Zhao and others [48]). A consensus seems to have been reached regarding the protective role of $E R \beta$ against breast cancer development. No clinically validated cut-off has been defined for $E R \beta$; transcript levels are generally lower in tumor tissue than in normal tissue. The loss of $E R \beta$ expression by promoter methylation, frequently observed in breast tumors, has led to the hypothesis that $E R \beta$ is a possible tumor-suppressor gene [49]. The $E R \beta$ transcript level in breast cancers was analyzed in a recent study by Anders and colleagues [50]. With clinically annotated microarray data from 200 early-stage breast cancers in women, they observed that the $E R \beta$ transcript level was statistically lower in young women (younger than 45 years) than in older women (older than 65 years; $P=0.02$ ). As expected from these data, the present study confirmed the protective effect of $E R \beta$ in terms of locoregional control.

In younger women with breast cancer, a higher incidence of growth-factor receptors, namely HER2, was observed both in terms of protein expression, associated with a more-aggressive phenotype [51,52], and of HER2 gene expression with no predictive value for DFS [50].

Interestingly, the HER family and IGF1R have been shown to be intertwined with the estrogen-mediated signaling pathway [53].

Hormone receptors and growth-factor receptors act as mitogens, promoting cell proliferation in normal tissue and in breast carcinomas. Strong evidence suggests that IGF1, $H E R$, and estrogen-mediated signaling are closely connected [54]. HER1 (or EGFR) has been described as both a prognostic marker and a predictor of hormone-therapy resistance in breast cancer [55]. However, downregulation of EGFR has 
never been explored. The present study showed a trend toward an impact of low EGFR expression on locoregional recurrence in young women. No other effect was observed for any of the other growth-factor receptors.

Proliferation markers, included in the definition of histologic grading [14], are also prognostic factors associated with poor outcome, high locoregional recurrence rates [5,56], and predictive factors of the response to chemotherapy [15,57]. The levels of gene expression of two subunits of CAF-1 ( $p 150$ and p60) [58] and other proliferation markers (the classic KI67, cyclins $E 1$ and E2, and SKP2) were well correlated in the present study (data not shown) but were not associated with a higher risk of locoregional recurrence. One explanation could be a lack of statistical power, as most patients (68\%) in this series had grade 3 tumors.

The search for a signature associated with local recurrence for premenopausal women treated with breast-conserving therapies by using high-throughput gene-expression analyses is ongoing $[23,24,59]$. The fact that gene-expression levels of neither CYP19/aromatase nor GATA3 were found to be associated with risk of local recurrences in the two studies $[23,24]$ that gave information about the patients' age could reflect either the lower sensitivity of microarray data compared with RT-PCR or a difference in the studied populations. Correlations between quantitative RT-PCR measures and microarray data have been deceiving. Koscielny and associates [60] investigated the correlation between gene expressions evaluated by the qRT-PCR and microarrays in 42 colon tumors. Of 39 genes randomly selected for analysis by qRT-PCR, seven showed a correlation between microarrays and quantitative RT-PCR of 0.5 or less. The authors concluded that microarray and qRT-PCR data are not deterministically related and therefore not interchangeable.

\section{Conclusions}

The present results highlight the role of estrogen-signaling pathways, mainly CYP19/aromatase, GATA3, and ER $\beta$, in the risk of recurrence in young women with breast cancer. These preliminary results must be confirmed in a larger prospective study. One hypothesis would be that the higher the level of circulatory estrogen, the higher the risk of locoregional recurrence, whereas low tumor expression of aromatase and high tumor expression of GATA3 would reflect only the high plasma estrogen levels. However, recent data also give credit to the fact that breast cancer arising in young women is a distinct biologic entity driven by specific oncogenic pathways [50,61]. In conclusion, our results demonstrate that the hormone status is of extreme importance for the prognosis of premenopausal breast cancer patients. Although these findings must be confirmed in a larger prospective study on patients younger than 40 years, assessing the expression levels of hormone-related genes, among which aromatase, might contribute to predict disease outcome in young breast cancer patients.

\section{Competing interests}

The authors declare that they have no competing interests.

\section{Authors' contributions}

$M A B$ acquired clinical data and obtained funding for the study. MAB and PDC designed the study and drafted the manuscript. BSZ performed all histopathologic reviews. LDK, CTR, and $C B$ performed all RT-PCR experiments and analyzed the data. AS and NS performed all statistical analyses. MAB, LDK, $\mathrm{PDC}, \mathrm{AD}, \mathrm{NS}$, and $\mathrm{AS}$ analyzed and interpreted the data. MAB, LDK, PDC, AS, BSZ, AD, GA, PC, RS, NS, and AF helped in acquiring the data and critically revised the manuscript for important intellectual content. All authors read and approved the final manuscript.

\section{Additional files}

The following Additional files are available online:

\section{Additional file 1}

Table listing primer and probe sequences, PCR efficiencies, regression coefficient and references. See http://www.biomedcentral.com/content/ supplementary/bcr2343-S1.doc

\section{Additional file 2}

Provides information from publicly available geneexpression studies of women, younger than 40 years old, treated with breast conserving treatments and whole breast radiotherapy.

See http://www.biomedcentral.com/content/ supplementary/bcr2343-S2.doc

\section{Acknowledgements}

The authors thank the patients who participated in this study and all members of the Institut Curie Breast Cancer Study Group who contributed to this study. They also thank Chantal Gautier for her assistance in patient data management and Bas Kreike, Adam Cook, and Anthony Saul for their helpful suggestions.

This research was financed by the Institut Curie, the "Courir pour la vie, Courir pour Curie" association, the "Odyssea" association, and the PHRC 2006 (AOM 06 149).

\section{References}

1. Temple WJ, Russell ML, Parsons LL, Huber SM, Jones CA, Bankes J, Eliasziw M: Conservation surgery for breast cancer as the preferred choice: a prospective analysis. J Clin Oncol 2006, 24:3367-3373.

2. Clarke M, Collins R, Darby S, Davies C, Elphinstone P, Evans E, Godwin J, Gray R, Hicks C, James S, MacKinnon E, McGale P, McHugh T, Peto R, Taylor C, Wang Y: Effects of radiotherapy and of differences in the extent of surgery for early breast cancer on local recurrence and 15-year survival: an overview of the randomised trials. Lancet 2005, 366:2087-2106.

3. Engel J, Kerr J, Schlesinger-Raab A, Sauer H, Holzel D: Quality of life following breast-conserving therapy or mastectomy: 
results of a 5-year prospective study. Breast J 2004, 10:223-231.

4. Moyer A: Psychosocial outcomes of breast-conserving surgery versus mastectomy: a meta-analytic review. Health Psychol 1997, 16:284-298.

5. Vrieling C, Collette L, Fourquet A, Hoogenraad WJ, Horiot JC, Jager JJ, Bing Oei S, Peterse HL, Pierart M, Poortmans PM, Struikmans $\mathrm{H}$, Bogaert $\mathrm{W}$ Van den, Bartelink $\mathrm{H}$ : Can patient-, treatment- and pathology-related characteristics explain the high local recurrence rate following breast-conserving therapy in young patients? Eur J Cancer 2003, 39:932-944

6. Bollet MA, Sigal-Zafrani B, Mazeau V, Savignoni A, de la Rochefordiere A, Vincent-Salomon A, Salmon R, Campana F, Kirova YM, Dendale $R$, Fourquet $A$ : Age remains the first prognostic factor for loco-regional breast cancer recurrence in young $(<40$ years) women treated with breast conserving surgery first. Radiother Oncol 2007, 82:272-280.

7. Oh JL, Bonnen M, Outlaw ED, Schechter NR, Perkins GH, Strom EA, Babiera G, Oswald MJ, Allen PK, Thames HD, Buchholz TA: The impact of young age on locoregional recurrence after doxorubicin-based breast conservation therapy in patients 40 years old or younger: how young is "young"? Int J Radiat Oncol Biol Phys 2006, 65:1345-52.

8. Pike MC, Spicer DV, Dahmoush L, Press MF: Estrogens, progestogens, normal breast cell proliferation, and breast cancer risk. Epidemiol Rev 1993, 15:17-35

9. Chen JQ, Brown TR, Yager JD: Mechanisms of hormone carcinogenesis: evolution of views, role of mitochondria. Adv Exp Med Biol 2008, 630:1-18.

10. Yager JD, Davidson NE: Estrogen carcinogenesis in breast cancer. N Engl J Med 2006, 354:270-282.

11. Nolan T, Hands RE, Bustin SA: Quantification of mRNA using real-time RT-PCR. Nat Protoc 2006, 1:1559-1582.

12. Larionov A, Krause A, Miller W: A standard curve based method for relative real time PCR data processing. BMC Bioinformatics 2005, 6:62.

13. Sobin LH, Wittekind C: TNM Classification of Malignant Tumours. New York: Wiley-Liss; 2002.

14. Elston CW, Ellis IO: Pathological prognostic factors in breast cancer, I: the value of histological grade in breast cancer: experience from a large study with long-term follow-up. Histopathology 1991, 19:403-410.

15. Vincent-Salomon $A$, Rousseau $A$, Jouve $M$, Beuzeboc $P$, SigalZafrani B, Freneaux P, Rosty C, Nos C, Campana F, Klijanienko J, Al Ghuzlan A, Sastre-Garau X: Proliferation markers predictive of the pathological response and disease outcome of patients with breast carcinomas treated by anthracycline-based preoperative chemotherapy. Eur J Cancer 2004 40:1502-1508

16. Balaton $\mathrm{AL}$, Coindre JM, Collin F, Ettore F, Fiche $\mathrm{M}$, Jacquemier J, Le Doussal V, Mandard AM, Mathieu MC, Migeon C, SimonyLafontaine J, Treilleux I, Verriele V, Vilain MO, Zafrani B: [Recommendations for the immunohistochemical evaluation of hormone receptors on paraffin sections of breast cancer: Study Group on Hormone Receptors using Immunohistochemistry FNCLCC/AFAQAP: National Federation of Centres to Combat Cancer/French Association for Quality Assurance in Pathology]. Ann Pathol 1996, 16:144-148.

17. Antonini $\mathrm{N}$, Jones $\mathrm{H}$, Horiot JC, Poortmans $\mathrm{P}$, Struikmans $\mathrm{H}$, Van den Bogaert W, Barillot I, Fourquet A, Jager J, Hoogenraad W, Collette L, Pierart M, Hart G, Bartelink H: Effect of age and radiation dose on local control after breast conserving treatment: EORTC trial 22881-10882. Radiother Oncol 2007, 82:265-271.

18. Bartelink H, Horiot JC, Poortmans $P$, Struikmans $H$, Bogaert $W$ Van den, Barillot I, Fourquet A, Borger J, Jager J, Hoogenraad W, Collette $L$, Pierart $M$ : Recurrence rates after treatment of breast cancer with standard radiotherapy with or without additional radiation. N Engl J Med 2001, 345:1378-1387.

19. de Cremoux $P$, Bieche I, Tran-Perennou $C$, Vignaud S, Boudou E, Asselain B, Lidereau R, Magdelenat H, Becette V, Sigal-Zafrani B, Spyratos F: Inter-laboratory quality control for hormonedependent gene expression in human breast tumors using real-time reverse transcription-polymerase chain reaction. Endocr Relat Cancer 2004, 11:489-495.

20. de Cremoux $P$, Jourdan-Da-Silva N, Couturier J, Tran-Perennou $C$ Schleiermacher G, Fehlbaum P, Doz F, Mosseri V, Delattre O, Klijanienko J, Vielh $\mathrm{P}$, Michon J: Role of chemotherapy resistance genes in outcome of neuroblastoma. Pediatr Blood Cancer 2007, 48:311-317.

21. dbEST, htgs and $\mathrm{nr}$ data bases [http://blast.ncbi.nlm.nih.gov]

22. Cox DR, Oakes D: Analysis of Survival Data. London: Chapman \& Hall; 1984.

23. Kreike B, Halfwerk $H$, Armstrong $N$, Bult $P$, Foekens JA, Veltkamp SC, Nuyten DS, Bartelink H, Vijver MJ van de: Local recurrence after breast-conserving therapy in relation to gene expression patterns in a large series of patients. Clin Cancer Res 2009, 15:4181-90.

24. Nuyten DS, Kreike B, Hart AA, Chi JT, Sneddon JB, Wessels LF, Peterse HJ, Bartelink $\mathrm{H}$, Brown PO, Chang HY, Vijver MJ van de: Predicting a local recurrence after breast-conserving therapy by gene expression profiling. Breast Cancer Res 2006, 8:R62.

25. Holli K, Isola J: Effect of age on the survival of breast cancer patients. Eur J Cancer 1997, 33:425-428.

26. Miki Y, Suzuki T, Tazawa C, Yamaguchi Y, Kitada K, Honma S, Moriya T, Hirakawa H, Evans DB, Hayashi S, Ohuchi N, Sasano H: Aromatase localization in human breast cancer tissues: possible interactions between intratumoral stromal and parenchymal cells. Cancer Res 2007, 67:3945-3954.

27. Santner SJ, Pauley RJ, Tait L, Kaseta J, Santen RJ: Aromatase activity and expression in breast cancer and benign breast tissue stromal cells. J Clin Endocrinol Metab 1997, 82:200-208.

28. Yue W, Wang JP, Hamilton CJ, Demers LM, Santen RJ: In situ aromatization enhances breast tumor estradiol levels and cellular proliferation. Cancer Res 1998, 58:927-932.

29. Chen S, Zhou D, Okubo T, Kao YC, Yang C: Breast tumor aromatase: functional role and transcriptional regulation. Endocr Relat Cancer 1999, 6:149-156.

30. Chetrite GS, Cortes-Prieto J, Philippe JC, Wright F, Pasqualini JR: Comparison of estrogen concentrations, estrone sulfatase and aromatase activities in normal, and in cancerous human breast tissues. J Steroid Biochem Mol Biol 2000, 72:23-27.

31. Smith IE, Dowsett M: Aromatase inhibitors in breast cancer. $N$ Engl J Med 2003, 348:2431-2442.

32. Wang $Y, Y e L$, Leung LK: A positive feedback pathway of estrogen biosynthesis in breast cancer cells is contained by resveratrol. Toxicology 2008, 248:130-135.

33. Galmiche G, Corvaisier S, Kottler ML: Aromatase gene expression and regulation in the female rat pituitary. Ann NYAcad Sci 2006, 1070:286-292.

34. Pauley RJ, Santner SJ, Tait LR, Bright RK, Santen RJ: Regulated CYP19 aromatase transcription in breast stromal fibroblasts. $J$ Clin Endocrinol Metab 2000, 85:837-846.

35. Zhang Z, Yamashita H, Toyama T, Omoto $Y$, Sugiura H, Hara $Y$, $\mathrm{Wu} \mathrm{X}$, Kobayashi S, Iwase H: Quantitative determination, by real-time reverse transcription polymerase chain reaction, of aromatase mRNA in invasive ductal carcinoma of the breast. Breast Cancer Res 2003, 5:R250-R256.

36. Miller WR, Hawkins RA, Forrest AP: Significance of aromatase activity in human breast cancer. Cancer Res 1982, 42:3365s-3368s.

37. Silva MC, Rowlands MG, Dowsett M, Gusterson B, McKinna JA, Fryatt I, Coombes RC: Intratumoral aromatase as a prognostic factor in human breast carcinoma. Cancer Res 1989 49:2588-2591.

38. Evans TR, Rowlands MG, Silva MC, Law M, Coombes RC: Prognostic significance of aromatase and estrone sulfatase enzymes in human breast cancer. J Steroid Biochem Mol Biol 1993, 44:583-587.

39. Sasano H, Frost AR, Saitoh R, Harada N, Poutanen M, Vihko R, Bulun SE, Silverberg SG, Nagura H: Aromatase and 17 betahydroxysteroid dehydrogenase type 1 in human breast carcinoma. J Clin Endocrinol Metab 1996, 81:4042-4046.

40. Salhab M, Reed MJ, AI Sarakbi W, Jiang WG, Mokbel K: The role of aromatase and 17-beta-hydroxysteroid dehydrogenase type 1 mRNA expression in predicting the clinical outcome of human breast cancer. Breast Cancer Res Treat 2006, 99:155-162.

41. Sorlie T, Perou CM, Tibshirani R, Aas T, Geisler S, Johnsen $H_{1}$ Hastie T, Eisen MB, Rijn M van de, Jeffrey SS, Thorsen T, Quist H, Matese JC, Brown PO, Botstein D, Eystein Lonning P, BorresenDale AL: Gene expression patterns of breast carcinomas distinguish tumor subclasses with clinical implications. Proc Nat Acad Sci USA 2001, 98:10869-10874. 
42. Sorlie T, Tibshirani R, Parker J, Hastie T, Marron JS, Nobel A, Deng $\mathrm{S}$, Johnsen H, Pesich R, Geisler S, Demeter J, Perou CM, Lonning PE, Brown PO, Borresen-Dale AL, Botstein D: Repeated observation of breast tumor subtypes in independent gene expression data sets. Proc Natl Acad Sci USA 2003, 100:8418-8423.

43. Bertucci F, Houlgatte R, Benziane A, Granjeaud S, Adelaide J, Tagett R, Loriod B, Jacquemier J, Viens P, Jordan B, Birnbaum D, Nguyen C: Gene expression profiling of primary breast carcinomas using arrays of candidate genes. Hum Mol Genet 2000, 9:2981-2991.

44. Aebi S, Gelber S, Castiglione-Gertsch M, Gelber RD, Collins J, Thurlimann B, Rudenstam CM, Lindtner J, Crivellari D, CortesFunes H, Simoncini E, Werner ID, Coates AS, Goldhirsch A: Is chemotherapy alone adequate for young women with oestrogen-receptor-positive breast cancer? Lancet 2000, 355:1869-1874.

45. Mehra R, Varambally S, Ding L, Shen R, Sabel MS, Ghosh D, Chinnaiyan AM, Kleer CG: Identification of GATA3 as a breast cancer prognostic marker by global gene expression metaanalysis. Cancer Res 2005, 65:11259-11264.

46. Oh DS, Troester MA, Usary J, Hu Z, He X, Fan C, Wu J, Carey LA, Perou CM: Estrogen-regulated genes predict survival in hormone receptor-positive breast cancers. J Clin Oncol 2006, 24:1656-1664.

47. Voduc D, Cheang M, Nielsen T: GATA-3 expression in breast cancer has a strong association with estrogen receptor but lacks independent prognostic value. Cancer Epidemiol Biomarkers Prev 2008, 17:365-373.

48. Zhao C, Dahlman-Wright K, Gustafsson JA: Estrogen receptor beta: an overview and update. Nucl Recept Signal 2008, 6:e003.

49. Garinis GA Patrinos GP Spanakis NE, Menounos PG: DNA hypermethylation: when tumour suppressor genes go silent. Hum Genet 2002, 111:115-127.

50. Anders CK, Hsu DS, Broadwater G, Acharya CR, Foekens JA, Zhang Y, Wang Y, Marcom PK, Marks JR, Febbo PG, Nevins JR, Potti A, Blackwell KL: Young age at diagnosis correlates with worse prognosis and defines a subset of breast cancers with shared patterns of gene expression. J Clin Oncol 2008, 26:3324-3330.

51. Hartley MC, McKinley BP, Rogers EA, Kalbaugh CA, Messich HS, Blackhurst DW, Lokey JS, Trocha SD: Differential expression of prognostic factors and effect on survival in young $(<$ or $=40)$ breast cancer patients: a case-control study. Am Surg 2006, 72:1189-1194. discussion 1194-1185.

52. Agrup M, Stal O, Olsen K, Wingren S: C-erbB-2 overexpression and survival in early onset breast cancer. Breast Cancer Res Treat 2000, 63:23-29.

53. Hamelers $\mathrm{IH}$, Steenbergh $\mathrm{PH}$ : Interactions between estrogen and insulin-like growth factor signaling pathways in human breast tumor cells. Endocr Relat Cancer 2003, 10:331-345. Review.

54. Hayashi S, Sakamoto T, Inoue A, Yoshida N, Omoto Y, Yamaguchi $Y$ : Estrogen and growth factor signaling pathway: basic approaches for clinical application. J Steroid Biochem Mol Biol 2003, 86:433-442.

55. Nicholson RI, Gee JM, Knowlden J, McClelland R, Madden TA, Barrow $D$, Hutcheson I: The biology of antihormone failure in breast cancer. Breast Cancer Res Treat 2003, 80(suppl 1):S29-S34. discussion S35.

56. Elkhuizen PH, Voogd AC, Broek LC van den, Tan IT, van Houwelingen $\mathrm{HC}$, Leer JW, Vijver MJ van de: Risk factors for local recurrence after breast-conserving therapy for invasive carcinomas: a case-control study of histological factors and alterations in oncogene expression. Int J Radiat Oncol Biol Phys 1999, 45:73-83.

57. Andre F, Khalil A, Slimane K, Massard C, Mathieu MC, Vignot S, Assi H, Delaloge S, Spielmann M: Mitotic anthracycline-based chemotherapy in patients with early breast cancer. J Clin Oncol 2005, 23:2996-3000.

58. Polo SE, Theocharis SE, Klijanienko J, Savignoni A, Asselain B, Vielh P, Almouzni G: Chromatin assembly factor-1, a marker of clinical value to distinguish quiescent from proliferating cells. Cancer Res 2004, 64:2371-2381.

59. Nimeus-Malmstrom E, Ritz C, Eden P, Johnsson A, Ohlsson M, Strand C, Ostberg G, Ferno M, Peterson C: Gene expression profilers and conventional clinical markers to predict distant recurrences for premenopausal breast cancer patients after adjuvant chemotherapy. Eur J Cancer 2006, 42:2729-2737.

60. Koscielny S, Michiels S, Boige V, Hill C: Validation of microarray data by quantitative reverse-transcriptase polymerase chain reaction. J Clin Oncol 2005, 23:9439-9440. author reply 9440.

61. Anders CK, Acharya CR, Hsu DS, Broadwater G, Garman K, Foekens JA, Zhang Y, Wang Y, Marcom K, Marks JR, Mukherjee S, Nevins JR, Blackwell KL, Potti A: Age-specific differences in oncogenic pathway deregulation seen in human breast tumors. PLOS ONE 2008, 3:e1373. 